\title{
Analisis Jaringan Komunikasi pada Agribisnis Sayuran Organik di Kabupaten Bandung Barat
}

\section{Analysis of Communication Network in Organic Vegetable Agribusiness in Bandung Barat Regency}

\author{
Rani Andriani Budi Kusumo*), Anne Charina
}

Program Studi Agribisnis Fakultas Pertanian, Universitas Padjadjaran. Sumedang 45363, Indonesia

${ }^{*}$ E-mail korespondensi: rani.andriani@unpad.ac.id

Diterima: 9 Oktober 2020 | Disetujui: 3 September 2021 | Publikasi Online: 10 September 2021

\begin{abstract}
Organic vegetable business opportunities are quite potential with the spread of a healthy lifestyle through the consumption of organic products. The problems faced by organic vegetable farmers include the use of technology and information that is not optimal. This study aims to analyze the communication network on organic vegetable agribusiness in West Bandung Regency; and analyzing the relationship between the communication network and the capacity of organic vegetable farmers in West Bandung Regency. This research used quantitative methods with survey techniques. The total respondents who were analyzed were 105 organic vegetable farmers in Lembang, Cisarua and Parongpong Districts who were selected using systematic random sampling technique. The results of the sociogram analysis showed that the communication network in organic vegetable agribusiness has a personal structure that spreads centrally (interlocking personal network). This diffuse and concentrated pattern in each click occurred because the areas where farmers lived were far from one another and the ability of farmers to access information sources varied. Farmers who have high capacity in managing organic vegetable farming are generally active in seeking information, and are able to market their products directly to the modern retail market, whereas farmers with moderate capacity tend to establish contacts and relationships that are limited to their community.
\end{abstract}

Keywords: Communication network, farmer's capacity, organic vegetables

\section{ABSTRAK}

Peluang bisnis sayuran organik dewasa ini cukup potensial dengan merebaknya gaya hidup sehat melalui konsumsi produk organik. Permasalahan yang dihadapi petani sayur organik diantaranya adalah pemanfaatan teknologi dan informasi yang belum optimal. Penelitian ini bertujuan untuk menganalisis jaringan komunikasi pada agribisnis sayuran organik di Kabupaten Bandung Barat; serta menganalisis keterkaitan antara jaringan komunikasi dan kapasitas petani sayuran organik di Kabupaten Bandung Barat. Penelitian ini menggunakan metode kuantitatif dengan teknik survey. Total responden yang dianalisis sebanyak 105 orang petani sayuran organik di Kecamatan Lembang, Cisarua dan Parongpong yang dipilih dengan menggunakan teknik systematic random sampling. Hasil penelitian dari analisis sosiogram menunjukkan jaringan komunikasi pada agribisnis sayuran organik memiliki struktur personal yang menyebar memusat (interlocking personal network). Pola yang menyebar dan terpusat di masing-masing klik ini terjadi karena daerah tempat tinggal petani saling berjauhan dan kemampuan yang dimiliki petani dalam melakukan akses terhadap sumber-sumber informasi berbeda-beda. Petani yang memiliki kapasitas tinggi dalam mengelola usahatani sayuran organik umumnya aktif mencari informasi, serta mampu memasarkan produknya langsung ke pasar ritel modern, sedangkan bagi petani yang memiliki kapasitas tergolong sedang, mereka cenderung lebih sering menjalin kontak dan relasi sebatas pada komunitasnya.

Kata kunci: Jaringan komunikasi, kapasitas petani, sayuran organik

Content from this work may be used under the terms of the Creative Commons Attribution-ShareAlike 4.0 International. Any further distribution of this work must maintain attribution to the author(s) and the title of the work, journal citation and DOI.

Published under Department of Communication and Community Development Science, IPB University and in association with Perhimpunan Ahli Penyuluhan Pembangunan Indonesia.

E-ISSN: 2442-4110 | P-ISSN: 1858-2664 


\section{PENDAHULUAN}

Isu keberlanjutan saat ini merupakan isu yang sangat penting dalam pembangunan pertanian. Segala tindakan yang dilakukan dalam aktivitas usaha tani hendaknya peka terhadap kondisi lingkungan. Pertanian organik merupakan penerapan dari sistem pertanian berkelanjutan. Sistem pertanian organik merupakan salah satu alternatif solusi atas kegagalan sistem pertanian industrial (Zulvera et al., 2014). Sistem pertanian organik telah mengalami perkembangan pesat di negara-negara Eropa dan Amerika. Laju penjualan pangan organik di Negara-negara tersebut berkisar dari 20-25\% pertahun selama dekade terakhir (Zulvera et al., 2014).

International Federation of Organik Movements (IFOAM) menyatakan Indonesia termasuk salah satu negara yang masuk dalam The Ten Countries with the Largest Organik Area 2012 di kawasan Asia. Luas lahan organik di Asia adalah sebesar 3.756.584 hektar dengan sebaran luas lahan di Indonesia 62.127,82 hektar pada 2012 kemudian meningkat menjadi 76.013,20 hektar di 2013 sampai 2014. Sebagian besar lahan organik ini tesebar di Pulau Jawa. Lahan ini digunakan untuk mengusahakan tanaman pangan seperti: sayuran, kopi, dan padi organik.

Salah satu daerah penghasil produk pangan organik di Jawa Barat adalah Kabupaten Bandung Barat. Di Kabupaten Bandung Barat, pertanian organik banyak diusahakan di Kecamatan Lembang, Cisarua dan Parongpong. Komoditas yang banyak diusahakan di daerah tersebut adalah sayuran organik. Fenomena yang ditemui di lapangan adalah masih banyak petani organik yang belum sepenuhnya menjalankan budidaya sayuran organik sesuai dengan SOP. Sistem Pertanian Organik di Indonesia mengacu pada Standar Nasional Indonesia (SNI) yang dikeluarkan oleh Badan Standardisasi Nasional (BSN) Indonesia.

Hasil kajian riset pada tahun pertama menunjukkan baru sebagian petani yang sudah menjalankan usahatani sayuran organik sesuai dengan SOP (Charina et al., 2018). Lebih dari 50 persen petani hanya memenuhi 3-5 poin SOP dari 8 poin yang wajib diterapkan, hal ini mengindikasikan belum semua SOP budidaya sayuran organik diterapkan oleh petani. Bahkan sekitar 6 persen petani hanya memenuhi kurang dari 3 poin SOP (Tabel 1).

Tabel 1. Tingkat kesesuaian pelaksanaan usahatani dengan SOP Pertanian Organik (SNI Sistem Pangan Organik)

\begin{tabular}{lcc}
\hline \multicolumn{1}{c}{ Tingkat Kesesuaian dengan SOP } & Jumlah Responden (n) & Persentase (\%) \\
\hline Tinggi (terpenuhi 6-8 poin SOP, atau 75\%-100\%) & 7 & 11.67 \\
Sedang (terpenuhi 3-5 poin SOP, atau 37.5\%- 74.9\%) & 49 & 81.67 \\
$\begin{array}{l}\text { Rendah (hanya memenuhi < 3 poin SOP, atau kurang } \\
\text { dari 37.5\%) }\end{array}$ & 4 & 6.66 \\
\hline Total & 60 & 100 \\
\hline
\end{tabular}

Keputusan petani untuk mengadosi sebuah inovasi, dalam hal ini teknik budidaya sayuran organik dipengaruhi oleh beberapa faktor. Hasil analisis menunjukkan salah satu faktor yang berpengaruh signifikan terhadap keputusan petani untuk menerapkan sistem pertanian organik adalah ketersediaan informasi mengenai teknis budidaya sayuran organik (Charina et al., 2018). Sebagian besar petani mengatakan bahwa petani lebih banyak belajar mengenai sistem pertanian organik dari petani lainnya. Kegiatan dan materi penyuluhan dari pemerintah memang belum difokuskan pada usahatani sayuran organik, sehingga terkadang petani menemui kendala dalam teknis budidaya sayuran organik.

Dilain pihak, permintaan produk sayuran organik meningkat cukup signifikan beberapa tahun belakangan ini. Masyarakat semakin menyadari pentingnya menjaga kesehatan. Gaya hidup back to nature menjadi tren bagi sebagian masyarakat. Meskipun belum ada data yang pasti mengenai permintaan produk pangan organik di Indonesia, namun Organisasi Perdagangan Dunia (WTO) menyebutkan permintaan produk pertanian organik tumbuh 20 persen setiap tahun.

Tantangan utama dalam pengembangan agribisnis sayuran organik adalah terwujudnya kualitas, kuantitas dan kontinuitas yang sesuai dengan dinamika permintaan pasar. Namun dari sisi adopsi inovasi, petani sayuran organik di Kabupaten Bandung Barat belum sepenuhnya mampu menerapkan SOP sistem pertanian organik. 
Suryana (2005) menyebutkan pentingnya komunikasi teknologi pertanian untuk meningkatkan pengetahuan, sikap dan keterampilan petani dalam penerapan inovasi baru. Lebih lanjut Rangkuti, (2009) menjelaskan bahwa untuk membangun pertanian yang efektif dan efisien dengan memanfaatkan informasi teknologi dari berbagai sumber perlu memperhatikan jaringan komunikasi yang ada. (Rangkuti, 2009)(Rangkuti, 2009)(Rangkuti, 2009)(Rangkuti, 2009)Tampubolon (2002) menyebutkan bahwa pengelolaan agribisnis dimasa yang akan datang membutuhkan tiga hal utama, yaitu: (1) keakuratan informasi, baik yang berasal dari luar maupun dari dalam; (2) kecepatan merespons dan menganalisis informasi baru; dan (3) peningkatan sumber daya agribisnis yang berbasis pada manajemen informasi. Sistem informasi yang efektif secara prinsip mempunyai tiga peran utama dalam sistem agribisnis, yaitu: (1) menunjang kegiatan (bisnis) operasional, (2) menunjang manajemen dalam pengambilan keputusan, dan (3) menunjang keunggulan strategi kompetitif agribisnis (Wahyuni, Lubis, et al., 2017).

Pemahaman mengenai jaringan komunikasi, baik di dalam maupun luar kelompok sangat bermanfaat dalam menyusun strategi pembangunan agribisnis sayuran organik. Analisis jaringan komunikasi dalam agribisnis sayuran organik di Kabupaten Bandung Barat diharapkan dapat mengungkapkan kendala pengembangan agribisnis sayuran organik. Jaringan komunikasi diharapkan dapat memberikan gambaran keberadaan, peran dan sifat dari masing-masing pelaku yang terlibat dalam agribisnis sayuran organik.

Rogers \& Kincaid (1961) menyebutkan bahwa penguatan kelompok dapat dilakukan melalui penguatan jaringan komunikasi di dalam kelompok. Pembangunan agribisnis, dalam hal ini agribisnis sayuran organik memerlukan dukungan dari berbagai pihak. Setiawan (2012) menyebutkan pemberdayaan petani dapat dilakukan dengan mengaktifkan dan meningkatkan dinamika kelompok tani, organisasi petani, gabungan kelompok tani dan menciptakan jaringan komunikasi (juga jaringan kerjasama dan jaringan usaha) antar kelompok tani, gabungan kelompok tani atau koperasi petani dengan lembaga pendukung dan sumber informasi pertanian. Hasil penelitian Warriner \& Moul (1992) menunjukan bahwa secara parsial jaringan komunikasi di antara petani berpengaruh positif terhadap adopsi inovasi. Petani memerlukan kelembagaan yang kuat untuk dapat mencari dan memanfaatkan informasi untuk pengembangan usahataninya. Lebih lanjut, peningkatan kapasitas petani salah satunya dapat didorong oleh ketersediaan informasi mengenai pengelolaan usahatani. Melkote \& Steeves (2001) menyebutkan pentingnya berbagi informasi dan pengetahuan bagi pembangunan yang partisipatif dan komunikatif. Dalam hal ini, kapasitas petani erat kaitannya dengan kemampuan petani untuk mengelola usahatani sayuran organik sesuai dengan kaidah sistem pertanian organik untuk menghasilkan produk sayuran yang sehat dan aman serta sesuai dengan permintaan pasar.

Pemahaman mengenai keterkaitan antara jaringan komunikasi dan kapasitas petani sayuran organik diperlukan sebagai upaya untuk memperkuat kapasitas petani dilihat dari sisi interaksi dan akses terhadap informasi untuk meningkatkan kesejahteraan petani.

Berdasarkan pemaparan di atas, maka tujuan dari penelitian ini adalah untuk : 1) menganalisis jaringan komunikasi pada agribisnis sayuran organik di Kabupaten Bandung Barat; serta 2) menganalisis keterkaitan antara jaringan informasi dan kapasitas petani dalam menjalankan usahatani sayuran organik di Kabupaten Bandung Barat.

\section{METODE PENELITIAN}

Penelitian ini dilakukan pada bulan April hingga Oktober 2018 di tiga kecamatan di Kabupaten Bandung Barat, yaitu Kecamatan Lembang, Cisarua, dan Parongpong, yang merupakan lokasi usaha tani sayuran organik. Desain penelitian yang digunakan adalah kuantitatif dengan teknik survei.

Data yang dikumpulkan terdiri dari data primer dan data sekunder. Data primer diperoleh melalui wawancara kepada responden menggunakan kuesioner terstruktur; Sedangkan data sekunder diperoleh dari Badan Pusat Statistik, Dinas Pertanian Kabupaten Bandung Barat, jurnal ilmiah dan sumber lain yang relevan dengan penelitian ini.

Berdasarkan hasil penelusuran ke berbagai instansi, tidak diketahui secara pasti jumlah petani yang berusahatani sayuran organik di Kabupaten Bandung Barat. Neuman (2014) menyebutkan untuk ukuran populasi yang tidak diketahui secara jelas jumlahnya, jumlah sampel dapat diestimasi 
berdasarkan pendapat para ahli. Oleh karena itu, penentuan populasi petani sayuran organik dilakukan melalui diskusi dengan aparat pemerintah kecamatan dan penyuluh lapangan di lokasi penelitian. Pada tiap kecamatan yang merupakan daerah sentra sayuran (Lembang, Parongpong dan Cisarua), diperkirakan jumlah petani sayuran organik jumlahnya sekitar 50 orang, sehingga jumlah populasi petani sayuran organik di ketiga kecamatan diperkirakan berjumlah 150 orang. Selanjutnya, jumlah sampel ditentukan menggunakan rumus slovin berikut:

$$
n=\frac{N}{1+N e^{2}} \ldots \ldots \ldots
$$

Keterangan:

$\begin{array}{ll}\mathrm{n} & =\text { Ukuran Sampel } \\ \mathrm{N} & =\text { Ukuran Populasi } \\ e & =\text { Tingkat kesalahan }(5 \%)\end{array}$

Berdasarkan hasil perhitungan tersebut, diperoleh jumlah sampel sebanyak 105 orang petani sayuran organik. Jumlah tersebut dibagi rata di setiap kecamatan, sehingga pada masing-masing kecamatan diambil 35 orang petani sebagai responden. Selanjutnya pada setiap kecamatan, sampel dipilih dengan cara sampling acak sistematis, dimana sampel pertama harus dipilih secara acak, dan sampel berikutnya dipilih setelah selang waktu tertentu. Sampel pertama yang diambil dianggap random karena jumlah petani sayuran organik tidak diketahui, sehingga setiap petani memiliki kesempatan yang sama untuk dipilih sebagai sampel. Sampel kedua dari responden ke 105 dipilih pada interval dua orang petani sayuran organik yang ditemui. Hal ini berdasarkan pertimbangan lokasi lahan ataupun rumah petani yang terkadang berjauhan.

Variabel yang dianalisis dalam penelitian ini adalah: 1) Jaringan komunikasi, beberapa hal yang dianalisis diantaranya : identifikasi klik dalam suatu sistem, identifikasi peran khusus dalam jaringan komunikasi, misalnya sebagai pemimpin opini, liasion, jembatan atau terisolasi; dan 2) keterkaitan antara jaringan komunikasi dan kapasitas petani.

Informasi tentang jaringan sosial petani dapat diperoleh dengan meminta petani "menyebutkan maksimal tiga orang yang sering mereka ajak berdiskusi tentang keputusan pertanian" (Matuschke \& Qaim, 2009). Data yang diperoleh dari jawaban pertanyaan pertama digunakan untuk menganalisis jaringan sosial. Untuk menganalisis jaringan komunikasi dalam agribisnis sayuran organik dilakukan pendekatan sosiometri. Metode yang digunakan adalah dengan membuat matriks yang berisi data relasi terlebih dahulu. Pertanyaan sosiometri dalam penelitian ini meliputi jaringan komunikasi dalam teknik budidaya dan pemasaran hasil. Selanjutnya data relasi tersebut dianalisis menggunakan bantuan perangkat lunak UCINET untuk menggambarkan peran masing-masing pihak yang terlibat dalam budidaya dan pemasaran sayuran organik.

Keterkaitan antara jaringan komunikasi dan kapasitas petani dianalisis menggunakan statistik deskriptif dengan tabulasi silang. Analisis dilakukan untuk mendeskripsikan keterkaitan antara sumber informasi yang digunakan petani untuk memperoleh informasi tentang teknis budidaya dan pasar sayur organik dengan tingkat kapasitas petani.

\section{HASIL DAN PEMBAHASAN}

\section{Karakteristik Responden}

Karakteristik petani digambarkan melalui karakteristik demografis dan karakteristik usahatani. Berdasarkan kelompok umur, sebagian besar petani sayuran organik di Kabupaten Bandung Barat berada pada usia produktif (Tabel 2). Artinya petani masih memiliki kemampuan secara fisik dalam mengelola usahataninya. 
Tabel 2. Karakteristik responden

\begin{tabular}{lcc}
\hline \multicolumn{1}{c}{ Karakteristik } & Jumlah Responden (n) & Persentase (\%) \\
\hline Umur & & \\
\hline Produktif (15-64 tahun) & 99 & 94,29 \\
Non Produktif (>64 tahun) & 6 & 5,71 \\
\hline Tingkat Pendidikan & & - \\
\hline Tidak Sekolah & - & 46,67 \\
SD & 49 & 21,90 \\
SMP & 23 & 30,48 \\
SMA & 32 & - \\
Diploma & - & - \\
Sarjana & - & 20,95 \\
\hline Status Penguasaan Lahan & & 49,52 \\
\hline Milik & 22 & 7,62 \\
Sewa & 52 & 21,90 \\
Penggarap & 8 & \\
Milik + Sewa & 23 & 21,90 \\
\hline Luas Penguasaan Lahan & & 32,38 \\
\hline$<0,5$ Ha & 23 & 46,67 \\
0,5-1 Ha 1 Ha & 34 & \\
\hline Pengalaman usahatani sayuran konvensional & 49 & \\
(tahun) & & 50,48 \\
\hline 0-5 & & 46,67 \\
6-10 & 53 & 2,86 \\
\hline Pengalaman usahatani sayuran organik & 49 & \\
(tahun) & 3 & 12,38 \\
\hline 0-5 & & 14,29 \\
6-10 & & \\
11-15 & 13 & \\
\hline
\end{tabular}

Hampir separuh responden $(46,67 \%)$ menempuh pendidikan hanya hingga tingkat sekolah dasar. Pendidikan formal bukan menjadi faktor penentu bagi petani untuk berusahatani sayuran organik. Petani lebih banyak mendapatkan pengetahuan dan keterampilan budidaya sayuran organik berdasarkan pengalaman dan juga berbagai pelatihan yang berkonsentrasi pada aspek teknis, produksi, ekonomi, pemasaran serta hal lain yang terkait dengan usahataninya (P. Nuthall, 2005).

Sayuran organik memiliki segmentasi pasar yang berbeda dengan sayuran non organik. Konsumen sayuran organik pada umumnya adalah kelompok masyarakat kalangan menengah dan menengah atas. Oleh karena itu petani sayuran organik di Kabupaten Bandung Barat lebih banyak memasarkan produknya ke pasar terstruktur. Komoditas sayuran yang diusahakan oleh sebagian besar petani sayuran organik merupakan tanaman sayuran yang bernilai ekonomis tinggi. Sebagian petani tidak memiliki lahan sendiri untuk menjalankan usahataninya, dan mereka menyewa atau menggarap lahan milik orang lain. Luas lahan yang diusahakan oleh sebagian besar petani tergolong luas, yaitu diatas 1 Ha.

Sebagian besar petani memiliki pengalaman yang cukup dalam berusahatani sayuran. Petani pada umumnya pernah mengusahakan sayuran non organik sebelum beralih mengusahakan sayuran organik. Pengalaman petani dalam berusahatani berkaitan dengan pengetahuan dan keterampilan petani dalam menemukan solusi dan mengambil keputusan atas masalah yang petani hadapi.

\section{Kapasitas Petani dalam Agribisnis Sayuran Organik}

Kapasitas petani diukur melalui berbagai aspek yang terkait dengan kemampuan menjalankan usahatani. Nuthall (2009) juga menyebutkan bahwa kapasitas dapat didefinisikan sebagai kemampuan seseorang yang layak (termasuk motivasi). Kapasitas petani merupakan segala sesuatu yang ada dalam 
diri petani yang berkaitan dengan pengetahuan, sikap dan juga keterampilan dalam menjalankan aktivitas usahatani (Herman et al., 2008). Pada penelitian ini kapasitas petani diukur melalui variabel pengetahuan, sikap dan keterampilan petani dalam mengidentifikasi potensi usahatani, memanfaatkan peluang usahatani, mengatasi permasalahan, serta pemeliharaan keberlanjutan usahatani sayuran organik.

Kapasitas petani dikelompokkan ke dalam tiga kelas, yaitu rendah, sedang dan tinggi. Petani yang memiliki kapasitas yang tinggi ditunjukkan melalui skor yang tinggi yang menggambarkan kemampuan yang baik dalam menangkap peluang bisnis, mengatasi permasalahan dan memelihara keberlanjutan usahatani. Pada kasus petani kecil, dengan kepemilikan lahan sempit, gurem, umumnya kapasitas para petani kecil itu rendah karena berbagai keterbatasan yang dimilikinya (Aminah, 2015).

Hasil kajian sebelumnya yang dilakukan oleh Kusumo et al (2018) menunjukkan secara umum kapasitas sebagian besar petani (77\%) di Kabupaten Bandung Barat termasuk dalam kategori tinggi (Tabel 3). Hal tersebut menunjukkan bahwa sebagian besar petani sudah memiliki pengetahuan dan keterampilan yang baik dalam menjalankan usahataninya.

Tabel 3. Kapasitas petani sayuran organik di Kabupaten Bandung Barat

\begin{tabular}{lcc}
\hline \multicolumn{1}{c}{ Kapasitas Petani } & Jumlah $(\mathbf{n})$ & Persentase $(\boldsymbol{\%})$ \\
\hline Tinggi & 77 & 73,33 \\
Sedang & 28 & 26,67 \\
Rendah & 0 & 0 \\
\hline Jumlah & 105 & 100,00 \\
\hline
\end{tabular}

Kapasitas petani dalam menangkap peluang usaha ditunjukkan melalui kemampuan petani dalam mengidentifikasi dan menangkap peluang bisnis dengan melihat trend permintaan yang meningkat untuk produk pangan yang sehat. Hal tersebut akhirnya mendorong sebagian petani beralih dari usahtani sayuran non organik ke usahatani sayuran organik.

Dalam hal pemecahan masalah, petani sudah mampu mencari solusi dari permasalahan yang mereka hadapi. Ketika petani menemui masalah terutama dalam hal budidaya sayuran organik, petani biasanya berdiskusi dengan rekan sesama petani ataupun berdiskusi dalam pertemuan kelompok. Petani juga memiliki komitmen yang tinggi dalam memelihara keberlanjutan usahatani. Meskipun petani belum mampu sepenuhnya menjalankan kaidah budidaya sayuran organik, namun sistem budidaya yang dilakukan sudah mengarah pada cara yang ramah lingkungan. Berdasarkan penuturan petani, kendala terbesar dalam budidaya sayuran organik adalah jarak lahan yang berdekatan dengan lahan petani lain yang masih menjalankan usahatani sayuran non organik, akibatnya lahan mereka rentan tercemar bahan kimia yang pada akhirnya mempengaruhi kualitas produk sayuran organik. Pada kegiatan pemasaran hasil produksi, petani juga belum mengalami kendala yang berarti, mengatakan jarang merasakan kendala. Petani secara mandiri ataupun melalui kelompok cukup aktif untuk mencari dan mempelajari peluang pasar dari produk yang mereka hasilkan.

\section{Struktur Jaringan Komunikasi pada Kegiatan Budidaya dan Pemasaran Sayuran Organik di Kabupaten Bandung Barat}

Jaringan komunikasi merupakan gambaran dari siapa berbicara kepada siapa dalam kelompok. Jaringan komunikasi dapat menggambarkan komunikasi interpersonal, sehingga akan terbentuk pemuka-pemuka opini dan pengikut yang akan saling melakukan hubungan komunikasi dalam topik tertentu, yang terjadi dalam suatu sistem sosial tertentu dalam hal ini yang terjadi pada kelompok petani sayur organik di Kabupaten Bandung Barat. Dalam penelitian ini, membahas mengenai jaringan komunikasi yang terbentuk, rangkaian hubungan diantara individu sebagai akibat terjadinya pertukaran informasi terutama dalam hal budidaya sayuran organik dan pemasaran sayuran organik.

Sistem jaringan komunikasi petani sayuran di Kabupaten Bandung Barat terbentuk karena terjadi interaksi antarpetani sayuran dalam memberi informasi, menerima informasi dan menyebarluaskan informasi dengan pelaku lain yang terlibat seperti dinas, penyuluh, bandar. Sistem ini akan sangat bermanfaat bagi petani, untuk budidaya, petani sangat membutuhkan informasi terkait bibit unggul, pengentasan hama, teknologi terbarukan dan sebagainya. Sedangkan untuk informasi pasar, petani 
sangat membutuhkan informasi terkait jumlah permintaan penawaran, harga jual, pasar sasaran dan lain-lain. Dengan jaringan informasi yang baik diharapkan tidak ditemui kelangkaan informasi pada petani sayur organik.

Hasil analisis pada Gambar 1 menggambarkan struktur jaringan komunikasi dalam hal budidaya sayuran organik di Kabupaten Bandung Barat. Struktur jaringan komunikasi mengenai budidaya sayuran organik lebih terbuka karena pada klik yang terbentuk partisipan masih melakukan pertukaran informasi. Dari Gambar 1 juga terlihat terpusatnya setiap individu yang menjadi anggota klik pada satu individu yang menjadi tokoh sentral. Keadaan seperti ini yang mengakibatkan pola komunikasi petani sayuran terpusat pada satu individu dalam satu klik. Pada Gambar 1 terlihat struktur jaringan komunikasi mereka merupakan struktur personal yang menyebar memusat (interlocking personal network).

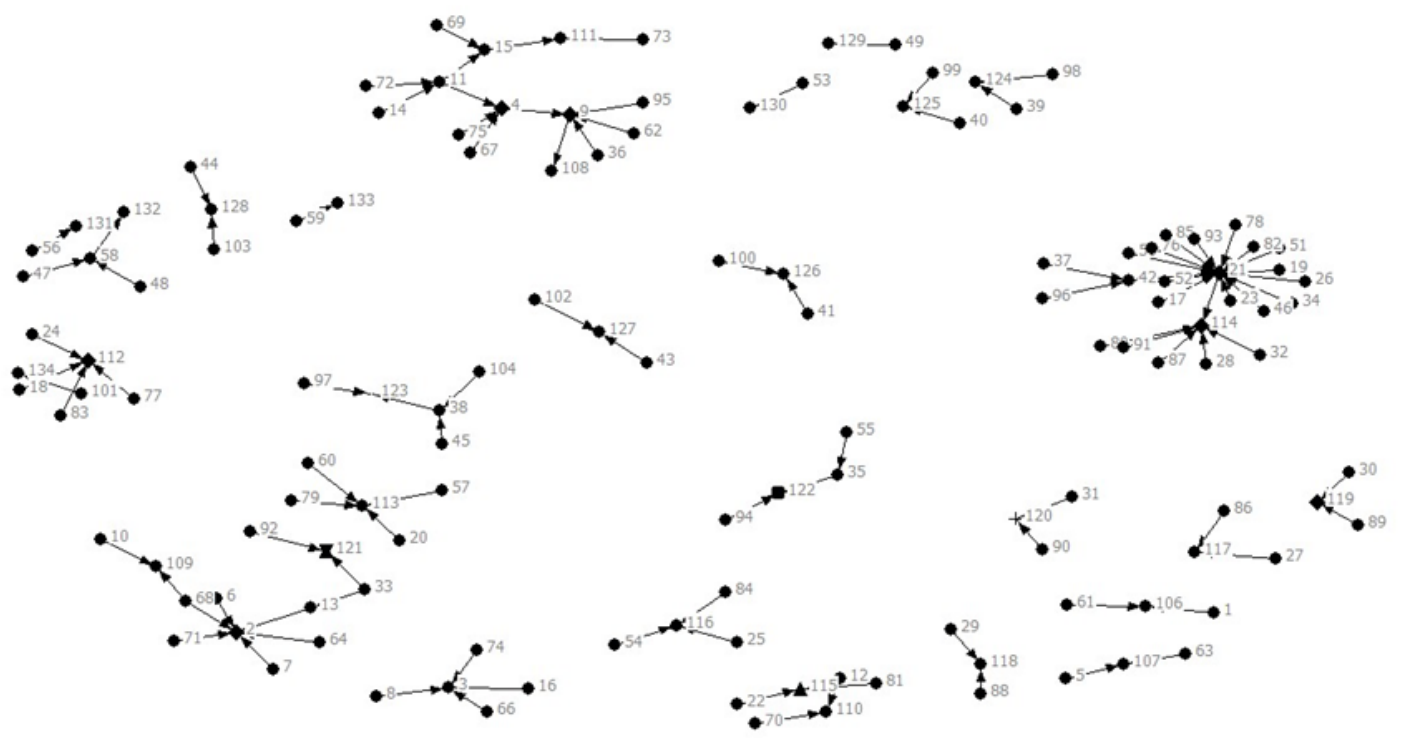

Gambar 1. Struktur Jaringan Komunikasi Pada Budidaya Sayuran Organik di Kabupaten Bandung Barat

Struktur seperti ini mengakibatkan individu petani yang merupakan anggota dalam sistem tersebut ataupun individu di luar anggota sistem dapat menjadi pusat untuk mendapatkan informasi mengenai budidaya (Bulkis, 2015). Jaringan komunikasi yang dimiliki oleh petani juga dapat menjadi sarana bagi petani untuk saling bertukar infromasi dan merupakan sumber infromasi yang efektif bagi petani (Crawford et al., 2015). Dalam jaringan komunikasi juga terdapat proses social learning dimana petani dapat saling belajar dan berbagi pengalaman dalam komunitasnya (Conley \& Christopher, 2001) serta dapat mendorong motivasi petani untuk menerapkan teknologi baru (Demiryurek et al., 2008). Dalam kasus ini, jaringan komunikasi yang dimiliki oleh petani dapat membantu petani untuk saling belajar teknik budidaya sayuran organik dan juga memecahkan masalah yang dihadapi.

Pola jaringan komunikasi yang menyebar dan terpusat di masing masing klik ini bisa terjadi karena daerah tempat tinggal petani jauh dari petani lain dan kemampuan yang dimiliki petani berbeda-beda dalam melakukan akses terhadap sumber-sumber informasi. Warriner \& Moul (1992) juga mengemukakan adopsi teknologi budidaya pertanian akan sangat dipengaruhi oleh kekerabatan dan hubungan komunikasi pribadi yang erat, disini lokasi sangat berperan dalam menentukan keeratan suatu hubungan. Lokasi yang berdekatan akan membentuk kekerabatan yang lebih personal.

Hubungan antara jaringan komunikasi dengan penerapan teknologi budidaya menunjukkan hubungan saling berkaitan. Dalam adopsi inovasi teknologi, jejaring komunikasi akan mempermudah penyampaian informasi secara cepat dan tepat sasaran (Hertanto et al., 2016). Jaringan komunikasi mengenai budidaya memiliki partisipan yang berperan sebagai gatekeeper dan cosmopolite. Individu petani sayuran yang berperan sebagai gatekeeper sekaligus berperan sebagai cosmopolite ditunjukkan oleh node 21, 9, 4, 2 pada sosiogram. Masing-masing dari mereka adalah ketua kelompok tani yang memiliki hubungan dengan beberapa sumber informasi di luar sistem. Sumber informasi di luar sistem 
yang berhubungan dengan node yaitu 112 (bandar) dan 114 (penyuluh). Dari sini terlihat dominasi ketua kelompok tani sebagai star yang paling banyak dihubungi karena merupakan sumber informasi paling mudah dan paling cepat didapatkan oleh petani (Tabel 4).

Tabel 4. Sumber Informasi Utama Bagi Petani

\begin{tabular}{|c|c|c|c|c|c|c|c|c|c|c|}
\hline \multirow{2}{*}{ Topik Diskusi } & \multicolumn{9}{|c|}{ Sumber Informasi $(n=105)$} & \multirow{2}{*}{ Total } \\
\hline & $\mathbf{A}$ & $\mathbf{B}$ & $\mathbf{C}$ & $\mathbf{D}$ & $\mathbf{E}$ & $\mathbf{F}$ & $\mathbf{G}$ & $\mathbf{H}$ & I & \\
\hline $\begin{array}{l}\text { 1. Teknis budidaya } \\
\text { sayuran organik }\end{array}$ & 9 & 29 & 38 & 14 & 3 & 4 & 6 & 0 & 2 & 105 \\
\hline $\begin{array}{l}\text { 2. Pengendalian } \\
\text { hama penyakit }\end{array}$ & 2 & 34 & 41 & 12 & 4 & 10 & 0 & 0 & 2 & 105 \\
\hline $\begin{array}{l}\text { 3. Pembuatan } \\
\text { pestisida nabati }\end{array}$ & 2 & 44 & 37 & 13 & 4 & 0 & 0 & 0 & 3 & 105 \\
\hline $\begin{array}{l}\text { 4. Pemilihan } \\
\text { komoditas yang } \\
\text { ditanam }\end{array}$ & 1 & 36 & 47 & 0 & 0 & 0 & 16 & 3 & 2 & 105 \\
\hline 5. Informasi pasar & 2 & 6 & 34 & 2 & 0 & 0 & 35 & 16 & 10 & 105 \\
\hline 6. Harga produk & 0 & 21 & 38 & 0 & 0 & 0 & 41 & 2 & 2 & 105 \\
\hline Total & 16 & 170 & 235 & 39 & 11 & 14 & 98 & 21 & 21 & \\
\hline $\begin{array}{l}\text { Keterangan: } \\
\text { A: Anggota Keluarga }\end{array}$ & \multicolumn{4}{|c|}{ B : Petani Lain } & \multicolumn{5}{|c|}{ C : Ketua Kelompok Tani } & \\
\hline D : Penyuluh & \multicolumn{4}{|c|}{ E : Profesional/Dosen } & \multicolumn{4}{|c|}{ F : Produsen pupuk/pestisida } & & \\
\hline G : Bandar & \multicolumn{4}{|c|}{ H : Pasar Modern } & \multicolumn{4}{|c|}{ I : Media Massa } & & \\
\hline
\end{tabular}

Dalam kegiatan pemasaran, struktur jaringan komunikasi yang terbentuk secara umum hampir sama dengan struktur jaringan komunikasi pada kegiatan budidaya sayuran organik. Pada Gambar 2 dapat dilihat bahwa struktur jaringan komunikasi pemasaran sayuran organik di Kabupaten Bandung Barat merupakan struktur personal yang menyebar memusat (interlocking personal network).

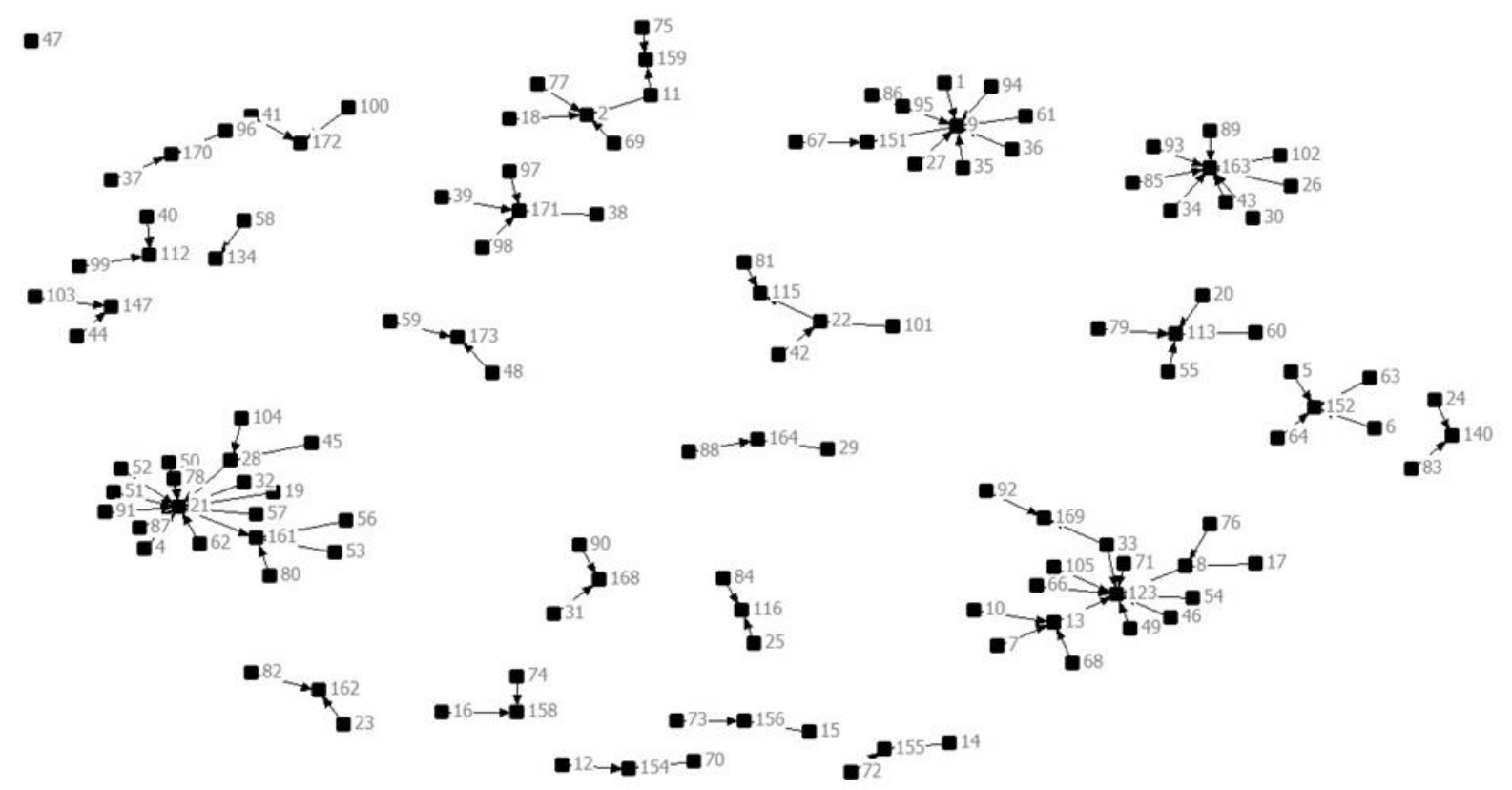

Gambar 2. Jaringan Komunikasi Pada Kegiatan Pemasaran Sayuran Organik di Kabupaten Bandung Barat

Individu petani sayuran organik yang berperan sebagai star sekaligus berperan sebagai gatekeeper dalam jaringan komunikasi pemasaran ditunjukkan oleh node $21,9,2$. Individu yang berperan sebagai star ditunjukkan oleh node yang memiliki derajat konektivitas tertinggi. Umumnya star merupakan pimpinan formal maupun informal dalam sebuah sistem yang dapat membimbing tingkah laku anggota sistem dan mempengaruhi keputusan mereka. Pada kasus ini, yang berperan sebagai star dalam 
jaringan pemasaran sayuran organik adalah ketua kelompok yaitu 21 (Pak Doyo), 9 (Bu Yusi), dan 2 (Pak Dedi). Ketua kelompok tani sebagai pusat informasi (star) memiliki kemampuan untuk berkomunikasi dan menjalin relasi dengan pihak lain di luar kelompok, seperti dengan penyuluh pertanian, pasar (ritel modern), eksportir, dan juga petani lain di luar kelompoknya. Kemampuan tersebut sangat diperlukan untuk mengembangkan usaha yang dijalankan oleh anggota. Informasi yang didapatkan oleh petani dari jaringan komunikasi yang dimilikinya, baik jaringan formal maupun informal dapat memberikan pengaruh yang positif dalam meningkatkan akses petani menuju pasar dan juga memberikan informasi harga yang lebih baik pada petani (Negi et al., 2018).

Pada penelitian ini terdapat juga individu di luar sistem yang memiliki derajat konektivitas yang tinggi, dimana individu tersebut banyak terhubung oleh petani yaitu 163 (Witar) dan 123 (yayang), keduanya merupakan bandar yang menampung hasil panen dari petani. Bagi sebagian petani, informasi pasar banyak didapat dari bandar, terkait pasar potensial, permintaan produk, serta harga pasar. Hal ini sangat membantu petani dalam menjalankan agribisnis sayuran organiknya.

Pada kegiatan pemasaran sayuran organik, ketua kelompok tani dan bandar merupakan sumber informasi utama bagi petani dalam mencari informasi pasar, seperti informasi mengenai tren permintaan komoditas dan juga harga sayuran organik (Tabel 4). Hal ini sejalan dengan yang dijelaskan oleh Sulistyowati et al (2013), bandar biasanya memberikan arahan mengenai jenis komoditas yang dibutuhkan pasar dan juga berperan dalam mengkoordinasi rantai nilai pasar agar dapat memenuhi kebutuhan pasar.

Berdasarkan hasil wawancara, sebagian besar petani memang memasarkan hasil usahataninya melalui kelompok tani atau dijual langsung ke bandar. Hal ini menunjukkan bahwa bandar merupakan sosok yang dapat diandalkan oleh petani dalam mencari informasi ataupun menjual hasil usahataninya. Umumnya, bandar atau tengkulak adalah orang yang sudah petani kenal, sehingga petani merasa mudah dalam mendapatkan informasi mengenai pasar sayuran organik dan juga merasa mudah dalam mengakses pasar yang selama ini menampung hasil panen petani.

Hanya sebagian kecil petani yang mencari informasi langsung ke pasar (node 123). Biasanya petani yang langsung mencari informasi ke pasar adalah petani yang melakukan kontak dan memasok langsung produk sayuran organik ke pasar modern. Belum semua petani mampu memasarkan produknya langsung ke pasar modern, karena terkendala kuantitas dan kontinyuitas pasokan. Ton et al (2018); Osmani \& Hossain (2015) menyebutkan hanya sebagian kecil petani skala kecil yang terlibat dalam perjanjian penjualan dengan pasar modern, petani yang menjalankan kontrak dengan pasar modern sebagian besar adalah petani dengan luas penguasaan lahan dan kepemilikan asset yang lebih besar dibandingan dengan petani lain pada umumnya.

Penggunaan media massa belum menjadi pilihan utama bagi petani untuk mendapatkan informasi pasar sayuran organik (Tabel 4), meskipun saat ini media massa seperti radio, televisi, surat kabar bahkan jaringan internet sudah tersedia secara baik di lokasi penelitian. Sebagian besar petani menilai informasi yang tersedia di media massa kurang akurat, misalnya informasi mengenai harga dan jumlah produksi yang dibutuhkan oleh pasar. Penelitian Hakim \& Sugihen (2009) menyebutkan pada dasarnya petani selalu mencari informasi akurat yang valid. Kesadaran dan minat menggunakan halhal baru berdasarkan informasi yang diperoleh, akan tumbuh ketika hal-hal baru tersebut terbukti hasilnya dan mendatangkan keuntungan bagi petani.

\section{Keterkaitan antara Jaringan Komunikasi dan Kapasitas Petani Sayuran Organik di Kabupaten Bandung Barat}

Penelitian Wahyuni, et al (2017) menunjukan bahwa kapasitas petani dalam kegiatan agribisnis dipengaruhi salah satunya oleh faktor eksternal yaitu jaringan komunikasi. Derajat keterhubungan individu dengan individu lainnya serta hubungan yang maksimal antar individu akan menentukan kapasitas individu itu sendiri. Keteraitan antara jaringan komunikasi dan kapasitas petani sayuran organik di Kabupaten Bandung Barat digambarkan melalui sumber informasi utama yang digunakan oleh petani untuk memperoleh informasi mengenai teknis budidaya dan pasar sayuran organik. 
Tabel 5. Kapasitas petani dan sumber informasi teknis budidaya sayuran organik

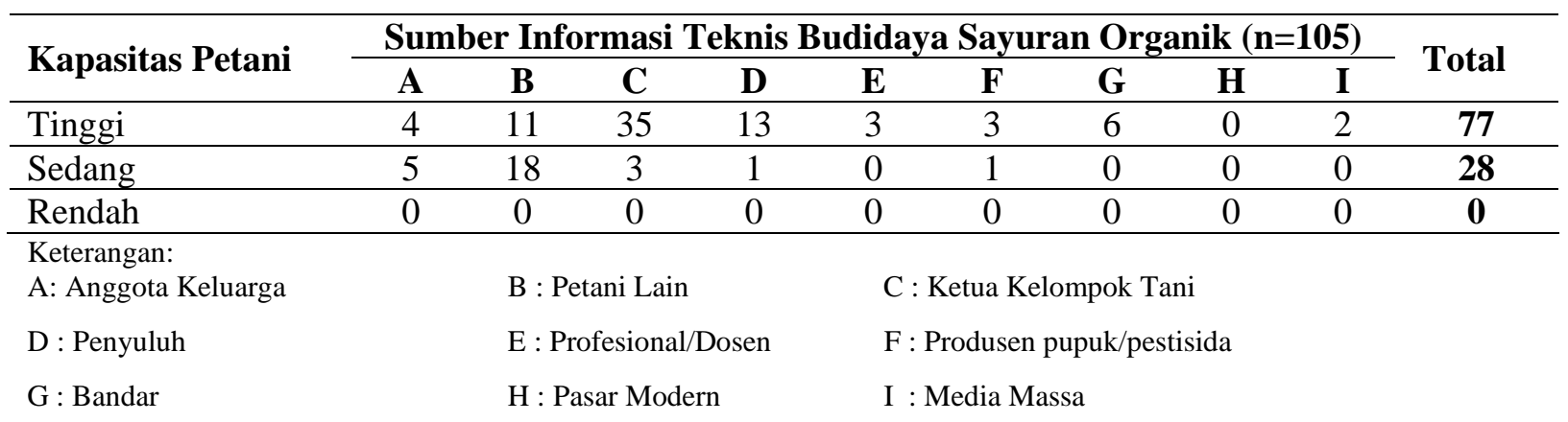

Pada Tabel 5 dapat dilihat bahwa petani yang memiliki kapasitas yang tinggi memperoleh sumber informasi tentang budidaya sayuran organik dari ketua kelompok tani, penyuluh ataupun dari petani lainnya. Vallaster \& De Chernatony (2005) mengemukakan bahwa ketua kelompok memiliki peranan paling sentral dalam menyebarkan ilmu dan pengetahuan di kelompoknya.

Tabel 6. Kapasitas petani dan sumber informasi pasar sayuran organik

\begin{tabular}{|c|c|c|c|c|c|c|c|c|c|c|}
\hline \multirow[b]{2}{*}{ Kapasitas Petani } & \multicolumn{9}{|c|}{ Sumber Informasi Pasar Sayuran Organik (n=105) } & \multirow[b]{2}{*}{ Total } \\
\hline & $\mathbf{A}$ & B & $\mathbf{C}$ & D & $\mathbf{E}$ & $\mathbf{F}$ & $\mathbf{G}$ & $\mathbf{H}$ & $\mathbf{I}$ & \\
\hline Tinggi & 0 & 2 & 22 & 2 & 0 & 0 & 26 & 15 & 10 & 77 \\
\hline Sedang & 2 & 4 & 12 & 0 & 0 & 0 & 9 & 1 & 0 & 28 \\
\hline Rendah & 0 & 0 & 0 & 0 & 0 & 0 & 0 & 0 & 0 & $\mathbf{0}$ \\
\hline $\begin{array}{l}\text { Keterangan: } \\
\text { A: Anggota Keluarga }\end{array}$ & \multicolumn{4}{|c|}{ B : Petani Lain } & \multicolumn{4}{|c|}{ C : Ketua Kelompok Tani } & & \\
\hline D : Penyuluh & \multicolumn{4}{|c|}{ E : Profesional/Dosen } & \multicolumn{4}{|c|}{ F : Produsen pupuk/pestisida } & & \\
\hline G : Bandar & \multicolumn{4}{|c|}{$\mathrm{H}$ : Pasar Modern } & \multicolumn{4}{|c|}{ I : Media Massa } & & \\
\hline
\end{tabular}

Pada Tabel 6 di bawah menunjukkan bahwa petani yang memiliki kapasitas tinggi dalam mengelola usahatani sayuran organik lebih aktif dalam mencari informasi pasar sayuran organik ke pihak yang berada di luar kelompoknya, seperti penyuluh, pasar modern dan juga melalui media massa. Terkait dengan peran mereka dalam jaringan komunikasi, petani yang memiliki kapasitas tinggi adalah petani yang berperan sebagai star dan juga lebih kosmopolit dibanding petani lainnya. Boz \& Akbay (2005); Bjomlund et al., (2009) menyebutkan petani dengan tingkat kosmopolitan tinggi lebih cepat dalam merespon perubahan yang terjadi. Selanjutnya, Nonaka \& Takeuchi (1995) menyebutkan kontak petani dengan pihak di luar komunitasnya dan intensitas penggunaan media berperan penting dalam meningkatkan interaksi untuk saling berbagi pemahaman dan pengetahuan. Jaringan komunikasi yang dimiliki oleh petani akan membantu petani untuk mengakses dan memperoleh informasi dari luar. Lebih lanjut, Tepic et al. (2013) menjelaskan frekuensi petani untuk berhubungan dengan jaringan komunikasinya juga berdampak pada kapasitas petani.

Hasil penelitian Wahyuni, et al. (2017) menunjukkan bahwa ketersediaan informasi dan dukungan lembaga penunjang juga turut mempengaruhi kapasitas petani. Selain itu, kedinamisan kelompok juga turut mempengaruhi kapasitas petani. Kelompok yang dinamis dapat menjadi wadah saling belajar dan bekerja sama antar petani Hal tersebut mengindikasikan bahwa jaringan komunikasi berkaitan dengan ketersediaan informasi yang relevan dan tepat waktu sehingga dapat meningkatkan kemampuan petani dalam mengidentifikasi peluang pasar, petani lebih mampu dan mandiri dalam menghadapi permasalahan dalam hal budidaya serta menjaga keberlanjutan usahatani sayuran organik.

\section{KESIMPULAN}

Jaringan komunikasi pada agribisnis sayuran organik memiliki struktur personal yang menyebar memusat (interlocking personal network). Pola yang menyebar dan terpusat di masing-masing kali ini terjadi karena daerah tempat tinggal petani saling berjauhan dan kemampuan yang dimiliki petani dalam melakukan akses terhadap sumber-sumber informasi berbeda-beda. Petani yang memiliki kapasitas tinggi dalam mengelola usahatani sayuran organik umumnya aktif dalam mencari informasi, 
serta mampu memasarkan produknya langsung ke pasar ritel modern, sedangkan bagi petani yang memiliki kapasitas tergolong sedang, mereka cenderung lebih sering menjalin kontak dan relasi sebatas pada komunitasnya. Pada umumnya ketua kelompok tani dan bandar menjadi sumber informasi utama bagi petani untuk memperoleh informasi pasar sayuran organik. Hal ini menunjukkan bahwa secara kelembagaan, pengembangan dan penguatan jaringan komunikasi yang dimiliki oleh petani dapat mendorong petani untuk mencari dan memanfaatkan informasi sebagai upaya untuk mengembangkan agribisnis sayuran organik.

\section{DAFTAR PUSTAKA}

Aminah, S. (2015). Pengembangan Kapasitas Petani Kecil Lahan Kering Untuk Mewujudkan Ketahanan Pangan. Jurnal Bina Praja, 7(3), 197-210.

Bjomlund, H., Nicol, L., \& Klein, K. . (2009). The adoption of improved irrigation technology and management practices-A study of two irrigation distritcs in Alberta, Canada. Agricultural Water Management, 96(1), 121-131.

Boz, I., \& Akbay, C. (2005). Factors influencing the adoption of maize in Kahramanmaras province of Turkey. Agricultural Economics, 33(3), 431-440.

Bulkis. (2015). Analisis jaringan komunikasi petani tanaman sayuran (kasus petani sayuran di Desa Egon, Kecamatan Waigette, Kabupaten Sikka, Provinsi Nusa Tenggara Timur). Jurnal Matematika, Sains Dan Teknologi, 16(2), 28-42.

Charina, A., Kusumo, R. A. B., Sadeli, A. H., \& Deliana, Y. (2018). Faktor-faktor yang mempengaruhi petani dalam menerapkan standar operasional prosedur ( SOP ) sistem pertanian organik di Kabupaten Bandung Barat. Jurnal Penyuluhan, 14(1), 82-92.

Conley, T., \& Christopher, U. (2001). Social learning through networks: the adoption of new agricultural technologies in Ghana. American Journal of Agricultural Economics, 83(3), 668673. https://doi.org/https://doi.org/10.1111/0002-9092.00188

Crawford, C., Grossman, J., Warren, S. T., \& Cubbage, F. (2015). Grower communication networks : information sources for organic farmers. Extension Journal, 53(3), 34-44.

Demiryurek, K., Erdem, H., Ceyhan, V., Atasever, S., \& Uysal, O. (2008). Agricultural information systems and communication networks: the case of dairy farmers in the Samsun Province of Turkey. Information Research, 13, 25-36.

Hakim, L., \& Sugihen, B. G. (2009). Keberdayaan petani sayuran dalam mengakses informasi pertanian di Sulawesi Selatan. Jurnal Penyuluhan, 5(1), 54-62.

Herman, S., Sumardjo, Asngrai, P. ., Tjitropranoto, P., \& Susanto, D. (2008). Kapasitas petani dalam mewujudkan keberhasilan usaha pertanian: kasus petani sayuran di Kabupaten Pasuruan dan Kabupaten Malang Provinsi Jawa Timur. Jurnal Penyuluhan, 4(1), 11-20.

Hertanto, D., Sugiyanto, \& Safitri, R. (2016). Analisis Struktur Jaringan Komunikasi dan Peran Aktor Dalam Penerapan Teknologi Budidaya Kentang. Jurnal Habitat, 27(2), 55-65.

Kusumo, R. A. B., Charina, A., Sukayat, Y., \& Mukti, G. W. (2018). Kapasitas petani dalam agribisnis sayuran organik di Kabupaten Bandung Barat. Agrivet, 6(2), 123-130.

Matuschke, I., \& Qaim, M. (2009). The impact of social networks on hybrid seed adoption in India. Agricultural Economics, 40(5), 493-505.

Melkote, S. R., \& Steeves, H. L. (2001). Communication for Development In The Third World: Theory And Practice For Empowerment. Sage Publication and Thousand Oaks.

Negi, D. S., Birthal, P. S., Roy, D., \& Khan, M. T. (2018). Farmers' choice of market channels and producer prices in India: Role of transportation and communication networks. Food Policy, 81, $106-121$.

Neuman, W. L. (2014). Social Research Methods: Qualitative and Quantitative Approaches (Seventh Edition) (Vol. 30, Issue 3). Pearson Education Limited. https://doi.org/10.2307/3211488

Nonaka, I., \& Takeuchi, H. (1995). The Knowledge-Creating Company: How Japanese Companies Create the Dynamics of Innovation. Oxford University Press.

Nuthall, P. (2009). Modelling the origins of managerial ability in agricultural production. Australian Journal of Agricultural and Resource Economics, 53(3), 413-436. https://doi.org/10.1111/j.1467-8489.2009.00459.x

Nuthall, P. . (2005). Managerial ability-a review of its basis and potential improvement using psychological concept. Agricultural Economics, 24(3), 247-262.

Osmani, A. ., \& Hossain, E. (2015). Market participation decision of smallholder farmers and its 
determinants in Bangladesh. Economics of Agriculture. Economics of Agriculture, 62(1), 163179.

Rangkuti, P. A. (2009). Adopsi inovasi traktor tangan di Kabupaten Cianjur, Jawa Barat. Agro Ekonomi, 27(1), 45-60.

Rogers, E. ., \& Kincaid, D. . (1961). Communication Network: Toward A New Paradigm for Research. Mc Millan Publishing.

Setiawan, I. (2012). Dinamika Pemberdayaan Petani: Sebuah Refleksi dan Generalisasi Kasus di Jawa Barat (Widya Padj).

Sulistyowati, L., Natawidjaja, R. S., \& Saidah, Z. (2013). Faktor-faktor sosial ekonomi yang mempengaruhi keputusan petani mangga terlibat dalam sistem informal dengan pedagang pengumpul. Sosiohumaniora, 15(3), 285-293.

Suryana, A. (2005). Rancangan dasar program rintisan dan akselerasi pemasyarakatan inovasi teknologi pertanian (Prima tani). Prosiding Lokakarya Nasional Prima Tani Mendukung Pengembangan KUAT Di Kalimantan Barat, 156.

Tampubolon, S. M. . (2002). Sistem dan Usaha Agribisnis (Harianto, R. Pambudy, T. Sipayung, \& Burhanuddin (eds.); 1st ed.). Pusat Studi Pembangunan IPB dan USESE Foundation.

Tepic, M., Trienekens, J. ., Hoste, R., \& Omta, S. W. . (2013). The influence of networking and absorptive capacity on the innovativeness of farmers in the Dutch pork sector. International Food and Agribusiness Management Review, 3(1), 1-34.

Ton, G., Vellema, W., Desiere, S., Weituschat, S., \& D’Haese, M. (2018). Contract farming for improving smallholder incomes: What can we learn from effectiveness studies? World Development, 104(1), 46-64.

Vallaster, C., \& De Chernatony, L. (2005). Internationalisation of Services Brands: The Role of Leadership During the Internal Brand Building Process. Journal of Marketing Management, 21(1-2), 181-203.

Wahyuni, S., Lubis, D. P., \& Sadono, D. (2017). Hubungan jaringan komunikasi dan dinamika kelompok dengan kapasitas petani dalam agribisnis padi organik di Jawa Barat. Jurnal $\begin{array}{llll}\text { Penyuluhan } & I P B, & 13(1), & 120 .\end{array}$ http://jagb.journal.ipb.ac.id/index.php/jupe/article/viewFile/15115/11632

Wahyuni, S., Sumardjo, Lubis, D. P., \& Sadono, D. (2017). Faktor-faktor yang berpengaruh terhadap dinamika kelompok dan kapasitas petani dalam agribisnis padi organik. Sosiohumaniora, 19(1), 21-28.

Warriner, G. ., \& Moul, T. . (1992). Kinship and personal communication network influences on the adoption of agriculture conservation technology. Rural Studies, 8(3), 279-291.

Zulvera, Sumardjo, Slamet, M., \& Ginting, B. (2014). Faktor-faktor yang berhunungan dengan keberdayaan petani sayuran organik di kabupaten Agam dan Tanah Datar, Provinsi Sumatera Barat. Mimbar, 30(1), 149-158. 